Historic, Archive Document

Do not assume content reflects current scientific knowledge, policies, or practices. 



\section{Fall 1921} 和 Spring 1922 STEELES’ POMONA NURSERIES

\section{Palmyra, N. J.}

A recent ruling of the Federal Horticuitural Board prevents the importation of Nursery Stock from Europe and many varieties of rare plants, such as Rhododendrons, Box, Magnolias, Japanese Maples, etc., etc., are not procurable, and will not be for many years.

We are fortunate in having a good stock of EVERGREENS, HARDY SHRUBS, SHADE TREES and PERENNIALS of our own growing and a general assortment of FRUIT TREES and FRUIT PLANTS to offer this fall and spring at the following prices.

PRICES in this list abrogate previous quotations. Our catalogue, printed some time ago is sent you only for descriptions etc. Prices therein are withdrawn.

GUARANTEE. We guarantee trees and plants to be first-class, healthy, true to name and quality represented, and to reach our customers in good condition, but we cannot be held responsible for their failure to grow through neglect, improper planting, unfavorable seasons, or other causes beyond our control, and we do not insure their living after having passed out of our hands and care.

\section{EVERGREENS}

\section{ABIES (Fir)}

Concolor, 5 to 6 feet, $\$ 10.00$ each.

Concolor Violacea, 4 to 5 feet, $\$ 6.00 ; 6$ to 8 feet, $\$ 10.00$.

Nordmanniana, 3 to 4 feet, $\$ 5.00 ; 5$ to 6 feet, $\$ 10.00$.

Veitchii, 3 feet, $\$ 5.00 ; 4$ to 6 feet, $\$ 8.00$; 8 feet, $\$ 10.00$.

\section{CUPRESSUS (Cypress)}

Glory of Boskoop, 3 feet, $\$ 5.00$ each; 4 to 5 feet, $\$ 8.00$ each.

Cryptomeria, Lobbii compacta, 6 to 8 feet, $\$ 10.00$ each; 8 to 10 feet, $\$ 15.00$.

\section{ILEX (Holly)}

Crenata (Japanese Holly) 2 feet, $\$ 2.50$; 3 feet, $\$ 5.00$ each.

Opaca (American), 2 to 3 feet, $\$ 2.50$; 3 to 4 feet, $\$ 4.00$ each.

\section{JUNIPERS}

Douglas Golden, $1 \mathrm{x} / 2$ to 2 feet, $\$ 2.50$; 2 to 3 feet spread, $\$ 5.00$ each.

Japan Golden, 10 to 12 inches, $\$ 2.50$; 18 inches to 2 feet, $\$ 3.50$ each.

Cannartii, 2 feet, $\$ 3.00 ; 3$ feet, $\$ 4.00 ; 4$ feet, $\$ 5.00$ each.

Irish, 2 to 3 feet, $\$ 2.50$ each. Swedish, $11 / 2$ to 2 feet, $\$ 2.50$ each.
Tripartita, 2 to 3 feet, $\$ 3.00$ each; 3 to 4 feet, $\$ 5.00$ each.

Chinensis argentea, variegata, 3 feet, $\$ 4.00 ; 4$ feet, $\$ 6.00$ each.

Pfitzeriana, 2 feet, $\$ 3.00 ; 3$ feet, $\$ 4.00$; 4 feet, $\$ 5.00$ each.

Virginiana, 2 to 3 feet, $\$ 2.50 ; 4$ feet, $\$ 4.00$; 5 feet, $\$ 5.00$ each.

Virginiana Glauca, 2 feet, $\$ 3.00 ; 3$ feet, $\$ 4.00 ; 4$ feet, $\$ 5.00$ each.

Elegantissima lee, 3 feet, $\$ 4.00 ; 4$ feet, $\$ 5.00$ each.

Schottii, 3 feet, $\$ 3.50 ; 4$ feet, $\$ 5.00$ each.

Stricta, $1 \mathrm{1} / 2$ feet, $\$ 2.00 ; 2$ feet, $\$ 3.00 ; 3$ feet, $\$ 5.00$.

\section{PICEA (Spruce)}

Alcockiana, 5 to 6 feet, $\$ 10.00$ each.

Hemlock, 2 feet, $\$ 2.00 ; 3$ feet, $\$ 3.00 ; 4$ feet, $\$ 5.00$; 6 to 8 feet, $\$ 10.00$ each.

Englemannii, 5 to 6 feet, $\$ 10.00$ to $\$ 20.00$ each.

Koster Blue, 2 to $2 \mathrm{r} / 2$ feet, $\$ 5.00 ; 5$ to 6 feet, $\$ 15.00$; Specimens from $\$ 25.00$ to $\$ 100.00$ each.

Orientalis, 3 feet, $\$ 4.00 ; 4$ to 5 feet, $\$ 7.00$ each.

Pungens glauca, 2 to $2 \mathrm{I} / 2$ feet, $\$ 5.00$.

Douglasii, 4 to 5 feet, $\$ 5.00$ each.

Douglasii glauca, 6 to 8 feet, $\$ 10.00$ each.

\section{PINES}

Austrian, 2 to 3 feet, $\$ 4.00 ; 3$ to 4 feet, $\$ 5.00$ each. 
Cembra, 2 feet, $\$ 3.00 ; 3$ feet, $\$ 5.00 ; 4$ feet, $\$ 7.00 ; 6$ feet, $\$ 15.00$ each.

lixcelsa, 5 to 6 feet, $\$ 10.00$ each.

Mugho, 1 to 2 feet, $\$ 3.00 ; 2$ to 3 feet, $\$ 5.00$ each.

Scotch, 4 to 5 feet, $\$ 8.00$ each.

\section{SCIADOPITYS (Umbrella Pine)}

3 to 4 feet, $\$ 7.00 ; 4$ to 5 feet, $\$ 10.00$ each.

\section{RETINOSPORA (Japan Cypress)}

Filifera, 2 to 3 feet, $\$ 3.00 ; 3$ to 4 feet, $\$ 5.00 ; 4$ to 6 feet, $\$ 8.00$ each.

Filifera Aurea, 2 feet, $\$ 3.50 ; 3$ feet, $\$ 5.00$ each.

Flavescens, 2 to $21 / 2$ feet, $\$ 3.50 ; 2 \frac{1}{2}$ to 3 feet, $\$ 5.00$ each.

Obtusa, 4 to 5 feet, $\$ 5.00$ each.

Obtusa Aurea, 3 feet, $\$ 5.00$ each.

Obtusa Crippsii, 2 to $21 / 2$ feet, $\$ 5.00 ; 2 \frac{1}{2}$ to 3 feet, $\$ 8.00$ each.

Pisifera, 1 to 2 feet, $\$ 2.00 ; 2$ to 3 feet, $\$ 3.00 ; 3$ to 4 feet, $\$ 5.00$ each.

Pisifera Aurea, 2 to 3 feet, $\$ 3.50 ; 3$ to 4 feet, $\$ 5.00 ; 5$ to 6 feet, $\$ 8.00$ each.

Plumosa, 2 feet, $\$ 2.50 ; 3$ feet, $\$ 4.00 ; 4$ feet, $\$ 5.00 ; 6$ feet, $\$ 10.00$ each.

Plumosa Aurea, 2 feet, $\$ 2.50 ; 3$ feet, $\$ 4.00 ; 5$ feet, $\$ 6.00$ each.

Squarosa Veitchi, 2 feet, $\$ 3.00 ; 3$ feet, $\$ 5.00$ each.

\section{TAXUS (Yew)}

Cuspidata Brevifolia, 2 feet, $\$ 3.00 ; 3$ feet, $\$ 5.00 ; 4$ feet, $\$ 8.00$ each.

Repandens, 1 to $11 / 2$ feet, $\$ 3.00$ each; 2 to 3 feet, $\$ 5.00$ each.

\section{THUYA (Arborvitae)}

American, 2 to 3 feet, $\$ 2.00$ each; 3 to 4 feet, $\$ 3.50$ each; 5 to 6 feet, $\$ 5.00$ each.

Geo. Peabody, 2 feet, $\$ 2.50 ; 3$ feet, $\$ 3.50$; 4 feet, $\$ 5.00 ; 6$ feet, $\$ 10.00$ each.

Borealis, 2 feet, $\$ 2.50 ; 3$ feet, $\$ 4.00 ; 4$ feet, $\$ 5.00$ each.

Columbiana, 4 to 5 feet, $\$ 6.00$ each; 6 to 8 feet, $\$ 10.00$ each.

Parsons Compacta, 1 foot, $\$ 2.00 ; 2$ feet, $\$ 3.00$ each.

Globosa, 1 foot, $\$ 2.00 ; 2$ feet, $\$ 3.00$ each.

Pyramidalis, 2 feet, $\$ 2.00$; 3 feet, $\$ 3.00$; 4 feet, $\$ 5.00 ; 5$ feet, $\$ 7.00$ each.

Vervaneana, 3 to 4 feet, $\$ 4.00 ; 4$ to 5 feet, $\$ 5.00$.

Standishi, 3 feet, $\$ 3.00 ; 4$ feet, $\$ 5.00 ; 5$ feet, $\$ 8.00$ each.

Wareana (Siberian) 2 feet, $\$ 3.00 ; 3$ feet, $\$ 4.00 ; 4$ feet, $\$ 5.00$ each.

Orientalis, 3 feet, $\$ 3.00 ; 4$ feet, $\$ 5.00 ; 6$ feet, $\$ 8.00$ each.

Elegantissima, 2 feet, $\$ 3.00 ; 3$ feet, $\$ 4.00$; 4 feet, $\$ 5.00 ; 5$ feet, $\$ 8.00$ each.

Semper Aurea, 1 foot, $\$ 2.00 ; 2$ feet, $\$ 5.00$ each.

Rosenthalii, 2 feet, $\$ 2.00 ; 3$ feet, $\$ 3.50$; 4 feet, $\$ 6.00$ each.

\section{DECIDUOUS TREES}

\section{MAPLES}

Japanese, blood red foliage, 2 feet, $\$ 3.00$; 3 feet, $\$ 5.00 ; 5$ feet, $\$ 10.00$ each.

Japanese, cut leaf, 2 feet, $\$ 5.00 ; 3$ feet, $\$ 10.00$ each.

Norway, 8 to 10 feet, $\$ 2.00 ; 10$ to 12 feet, $\$ 3.00 ; 12$ to 14 feet, $\$ 5.00$ each.

Schwedleri, 8 to 10 feet, $\$ 2.50 ; 10$ to 12 feet, $\$ 4.00$ each.

Sycamore, 8 to 10 feet, $\$ 2.50 ; 10$ to 12 feet, $\$ 4.00$ each.

Purple-leaf Sycamore, 8 to 10 feet, $\$ 3.00$; 10 to 12 feet, $\$ 5.00$ each.

Weirs cut leaf, 8 to 10 feet, $\$ 2.00 ; 10$ to 12 feet, $\$ 3.00$ each.

Sugar, 10 to 12 feet, $\$ 3.00 ; 12$ to 14 feet, $\$ 5.00$ each.

\section{HORSE CHESTNUT}

6 to 8 feet, $\$ 2.00 ; 8$ to 10 feet, $\$ 3.00$ each.

\section{BIRCH}

Cut leaf weeping, 8 to 10 feet, $\$ 2.50 ; 10$ to 12 feet, $\$ 3.50$ each.

American White, 6 to 8 feet, $\$ 1.50 ; 8$ to 10 feet, $\$ 2.50$ each.

Youngs Weeping, 4 to 5 feet, $\$ 5.00 ; 5$ to 6 feet, $\$ 8.00$ each.

CATALPA BUNGEI (Umbrella Tree)

2 year heads, $\$ 2.00$ each.

Speciosa, 6 to 8 feet, $\$ 1.00$ each; 8 to 10 feet, $\$ 2.00$.

\section{CERASUS (Cherry)}

Japonica Rosea, 5 to 6 feet, $\$ 2.00$ each. Rosea Pendula, 2 year heads, 5 to 6 feet, $\$ 5.00$ each.

Sinensis flore-pleno, 5 feet, $\$ 2.50$ each.

\section{CLADRASTIS}

6 to 8 feet, $\$ 3.00$ each.

\section{CORNUS (Dog Wood)}

White flowering, 4 to 5 feet, $\$ 3.00$ each; 5 to 6 feet, $\$ 4.00$ each.

Red flowering, 2 to 3 feet, $\$ 3.00$ each; 3 to 4 feet, $\$ 4.00$ each.

\section{GYMNOCLADUS (Ky. Coffee Tree)}

6 to 8 feet, $\$ 2.00 ; 8$ to 10 feet, $\$ 3.00$ each.

\section{FAGUS (Beech)}

American, 5 to 6 feet, $\$ 3.00$ each.

Fern leaf, 6 to 8 feet, $\$ 10.00$ each.

Cut leaf, 4 to 5 feet, $\$ 8.00$ each.

Weeping, 8 to 10 feet, $\$ 10.00$ to $\$ 25.00$ each.

Purple leaf, 4 to 5 feet, $\$ 5.00 ; 5$ to 6 feet, $\$ 8.00$ each.

Rivers Purple leaf, 4 to 5 feet, $\$ 5.00$; 6 to 8 feet, $\$ 8.00$ each. 


\section{LARIX (Larch)}

6 to 8 feet, $\$ 5.00 ; 8$ to 10 feet, $\$ 8.00$ each.

LIQUIDAMBAR (Sweet Gum)

6 to 8 feet, $\$ 2.00 ; 8$ to 10 feet, $\$ 2.50$ each.

\section{LIRIODENDRON (Tulip Tree)}

8 to 10 feet, $\$ 2.00 ; 10$ to 12 feet, $\$ 3.00$ each.

\section{MAGNOLIA}

Alexandrina, 3 to 4 feet, $\$ 5.00$ each.

Conspicua, 2 to 3 feet, $\$ 4.00 ; 3$ to 4 feet, $\$ 8.00$ each.

Glauca, 2 to 3 feet, $\$ 2.00$ each.

Lennei, 2 to 3 feet, $\$ 5.00 ; 3$ to 4 feet, $\$ 8.00$ each.

Soulangeana, 3 to 4 feet, $\$ 5.00 ; 4$ to 5 feet, $\$ 7.00$ each.

Speciosa, 2 to 3 feet, $\$ 5.00 ; 3$ to 4 feet, $\$ 8.00$ each.

Stellata, Halleana, 3 feet, $\$ 5.00$ each.

\section{MULBERRY (Morus)}

Weeping, 1-year heads, $\$ 3.00$ each; 2year heads, $\$ 4.00$ each; Specimens, $\$ 10.00$ each.

\section{PLATANUS (Oriental Plane)}

8 to 10 feet, $\$ 2.00 ; 10$ to 12 feet, $\$ 3.00$; 12 to 14 feet, $\$ 4.00$ each.

\section{POPLARS (Lombardy)}

8 to 10 feet, $\$ 1.50 ; 10$ to 12 feet, $\$ 2.00$; 12 to 14 feet, $\$ 5.00$ each.

\section{FLOWERING CRAB APPLE} (Bechtels)

2 to 3 feet, $\$ 1.50 ; 3$ to 4 feet, $\$ 2.00 ; 4$ to 5 feet, $\$ 5.00$ each.

\section{OAKS (Quercus)}

Scarlet Oak, 6 to 8 feet, $\$ 3.00 ; 8$ to 10 feet, $\$ 4.00 ; 10$ to 12 feet, $\$ 5.00$ each.

Pin Oak, 8 to 10 feet, $\$ 2.50 ; 10$ to 12 feet, $\$ 3.50 ; 12$ to 14 feet, $\$ 5.00$ each.

Pyramidal Oak, 6 to 8 feet, $\$ 3.50 ; 8$ to 10 feet, $\$ 5.00$ each.

Red Oak, 6 to 8 feet, $\$ 3.00 ; 8$ to 10 feet, $\$ 5.00$ each.

\section{SALISBURIA (Ginkgo Biloba)}

8 to 10 feet, $\$ 2.00 ; 10$ to 12 feet, $\$ 3.00$ each.

\section{WILLOW}

Weeping, 8 to 10 feet, $\$ 1.50$ each; 10 to 12 feet, $\$ 2.50 ; 12$ to 14 feet, $\$ 5.00$ each.

\section{$\mathrm{ASH}$}

European Mountain, 8 to 10 feet, $\$ 3.00$; 10 to 12 feet, $\$ 5.00$ each.

\section{LINDEN}

American, 8 to 10 feet, $\$ 2.00 ; .10$ to 12 feet, $\$ 3.00$ each.

Furopean Linden, 8 to 10 feet, $\$ 2.00$; 10 to 12 feet, $\$ 3.00$ each.

\section{ELM}

American, 8 to 10 feet, $\$ 2.00 ; 10$ to 12 feet, $\$ 3.00$; 12 to 14 feet, $\$ 5.00$ each. Camperdown Weeping, 3-year heads, 5 to 6 feet stems, $\$ 5.00$ each.

\section{HARDY FLOWERING SHRUBS}

ABELIA grandiflora, 1-year plants $35 \mathrm{c}$; 2 -year plants, 50c; extra heavy, $\$ 1.00$ each.

ALTHEAS, assorted variety, 2 to 3 feet, $50 \mathrm{c}$ each; 3 to 4 feet, $75 \mathrm{c}$.

AMYGDALUS (Almond), 2 to 3 feet, 50c each; 3 to 4 feet, $75 \mathrm{c}$ each.

ANDROMEDA, 1 to 2 feet, $\$ 1.50$ each.

AZALEA HINODEGIRI, 1 foot, \$1.50; 2 feet, $\$ 2.50$ each.

BERBERIS Purpurea, 2 to 3 feet, $75 \mathrm{c}$ each.

BERBERIS Thunbergii, 12 to 18 inches, $25 \mathrm{c} ; 18$ to 24 inches, $35 \mathrm{c} ; 2$ feet heavy, 50c.

BERBERIS Thunbergii, globe-shape specimens, $3 \times 3$ feet, $\$ 5.00$ each.

BUDDLEIA, 25c each.

CALLICARPA, 75c each.

CALYCANTHUS, 75c each.

CARAGANA, 75c each.

CLETHRA Alnifolia, 50c each.

CHIONANTHUS, White Fringe, $\$ 1.00$ each.

COLUTEA, 75c each.

CYDONIA Japonica, 75c each.

DESMODIUM, 50c each.

DEUTZIA, all varieties, 50c each.

EUONYMUS Alatus, 2 to 3 feet, 75c; 3 to 4 feet, $\$ 1.00$ each.

EXOCHORDA, 2 to 3 feet, $75 \mathrm{c}$; 3 to 4 feet, $\$ 1.00$ each.

FORSYTHIA, 2 to 3 feet, 50c; 3 to 4 feet, $75 \mathrm{c}$ each.

HAMAMELIS (Witch Hazel), 2 to 3 feet, 75c each.

HYDRANGEA P.G., extra heavy plants, 50c; tree form, $\$ 1.50$ each.

HYDRANGEA, Hills of Snow, extra heavy, 75c each.

HYPERICUM Aureum, 2 feet, 75c each. HYPERICUM Densiflorum, 2 to 3 feet, $75 \mathrm{c}$ each.

KALMIA (Laurel), 18 inches, $\$ 1.50 ; 2$ feet, $\$ 2.50$ each.

LONICERA (Honeysuckles), 75c each. PHILADELPHUS (Mock Orange), 75c each. 
RHODOTYPOS (kerria), 75c each.

RHUS (Purple Mist), 2 to 3 feet, $\$ 1.00$; 3 to 4 feet, $\$ 1.50$ each.

\section{SNOWBALL (Viburnun)}

Plicatum Japan, 2 to 3 feet, $\$ 1.00$ each. American, 2 to 3 feet, $75 \mathrm{c}$ each.

Tomentosum, 2 to 3 feet, $75 \mathrm{c}$ each.

Opulus, 2 to 3 feet, 75c each.

SPIREA, all varieties, 3 to 4 feet, $75 \mathrm{c}$; 4 to 5 feet, $\$ 1.00$ each.

STEPHANANDRA, 2 to 3 feet, $75 \mathrm{c}$ each.

SYMPHORICARPOS, 75c each.

\section{SYRINGA (Lilac)}

Charles Tenth, 2 to 3 feet, $75 \mathrm{c}$ each.

Japonica, 2 to 3 feet, $75 \mathrm{c}$ each.

President Grevy, 2 to 3 feet, 75 c; 3 to 4 feet, $\$ 1.50$ each.

Josikea, 2 to 3 feet, $75 \mathrm{c}$ each.

Persian White and Purple, 2 to 3 feet, $75 \mathrm{c}$ each.

Common Purple, 2 to 3 feet, 50c each. Common White, 2 to 3 feet, 50c each.

\section{TAMARIX}

Africana and Indica, 3 to 4 feet, $75 \mathrm{c}$ each.

\section{WEIGELA}

Six varieties, 2 to 3 feet, 50 c; 3 to 4 feet, $75 \mathrm{c}$ each.

\section{YUCCA (Adams Needle)}

$50 \mathrm{c}$ each.

\section{CALIFORNIA PRIVET}

12 to 18 inches, $\$ 5.00$ per $100 ; \$ 40.00$ per 1000.

18 to 24 inches, $\$ 6.00$ per $100 ; \$ 50.00$ per 1000.

2 to 3 feet, $\$ 8.00$ per $100 ; \$ 75.00$ per 1000 .

\section{GOLDEN PRIVET}

12 to 15 inches, $25 \mathrm{c}$ each; 18 inches to 2 feet, 50c each; globe-shape specimens, $2 \times 2$ feet, $\$ 3.00$ each; specimens $3 \times 3$ feet, $\$ 5.00$ each.

\section{VINES (Hardy Climbing)}

Akebia Quinata, 50c each.

Ampelopsis Veitchi, 25c each; extra heavy, $50 \mathrm{cl}$ each.

Ampelopsis Quinquefolia, 25c each; extra heavy, 50c each.
ARISTOLOCHIA (Dutchman's Ripe), $75 \mathrm{c}$ each.

CLEMATIS Henryi, 75c each.

CLEMATIS Jackmanii, 75c each.

CLEMATIS Edouard Andre, 75c each.

CLEMATIS Paniculata, 50c each.

DOLICHOS (Kudzu Vine) 50c each. EUONYMUS radicans var, 25c each.

HEDERA (English Ivy), 50c each; extra heavy, $75 \mathrm{c}$.

LONICERA (HONEYSUCKLE, Hall's Japan), 25c each.

TECOMA (Trumpet Vine), 50c each.

WISTERIA, Blue and White, $\$ 1.00$ each.

P FEONIES, $25 \mathrm{c}$ to $\$ 1.50$ each as per catalogue.

PHLOX, 25c each.

STEELES' EVERGREEN LAWN GRASS SEED, $\$ 6.00$ per bushel

\section{FRUIT TREES and FRUIT} PLANTS

APPLES, 1st class, 5 to 6 feet, $\$ 1.00$ each; $\$ 10.00$ per dozen.

APRICOTS, 1 st class, 4 to 5 feet, $\$ 1.00$ each; $\$ 10.00$ per dozen.

CHERRIES, 1st class, 5 to 6 feet, $\$ 1.00$ each; $\$ 10.00$ per dozen.

PLUMS, 1st class, 5 to 6 feet, $\$ 1.00$ each.

PEACHES, $1 \mathrm{st}$ class, 4 to 5 feet, $75 \mathrm{c}$ each; $\$ 8.00$ per dozen; $\$ 50.00$ per 100 .

PEARS, 1st class, 5 to 6 feet, $\$ 1.00$ each.

QUINCES, 1 st class, 3 to 4 feet, $\$ 1.00$ each.

BLACKBERRIES, all varieties, $\$ 1.50$ dozen; $\$ 5.00$ per 100 .

RASPBERRIES, all varieties, $\$ 1.50$ dozen; $\$ 5.00$ per 100 .

RHUBARB, 15c each; $\$ 1.50$ dozen.

GRAPES, all varieties, 2 -year old, $50 \mathrm{c}$ each; $\$ 5.00$ per dozen.

CURRANTS, 2-year old, 35c each; $\$ 3.50$ per dozen.

GOOSEBERRIES, 2-year old, 35c each; $\$ 3.50$ per dozen.

ASPARAGUS, 2-year old roots, $\$ 2.00$ per $100 ; \$ 10.00$ per 1000 .

STRAWBERRIES. Sold out.

LAWN GRASS SEED, STEELES' EVERGREEN, $\$ 6.00$ per bushel 